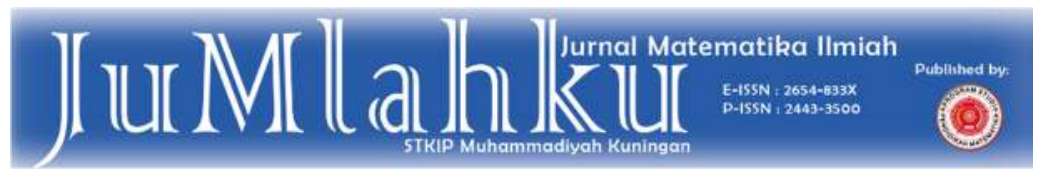

Submited: $2021-10-31$

Published: 2021-11-28

\title{
PENGARUH TEKNIK THINK-PAIR-SHARE DALAM STRATEGI KONFLIK KOGNITIF TERHADAP PENINGKATAN KEMAMPUAN PEMECAHAN MASALAH MATEMATIS SISWA
}

\author{
Handayani Eka Putria), Yosi Adiputra ${ }^{\text {b) }}$ \\ a,b Akademi Maritim Cirebon, Jawa Barat \\ Corresponding Author : handayaniekaputri1990@gmail.com a) \\ yosiadiputra@gmail.com b)
}

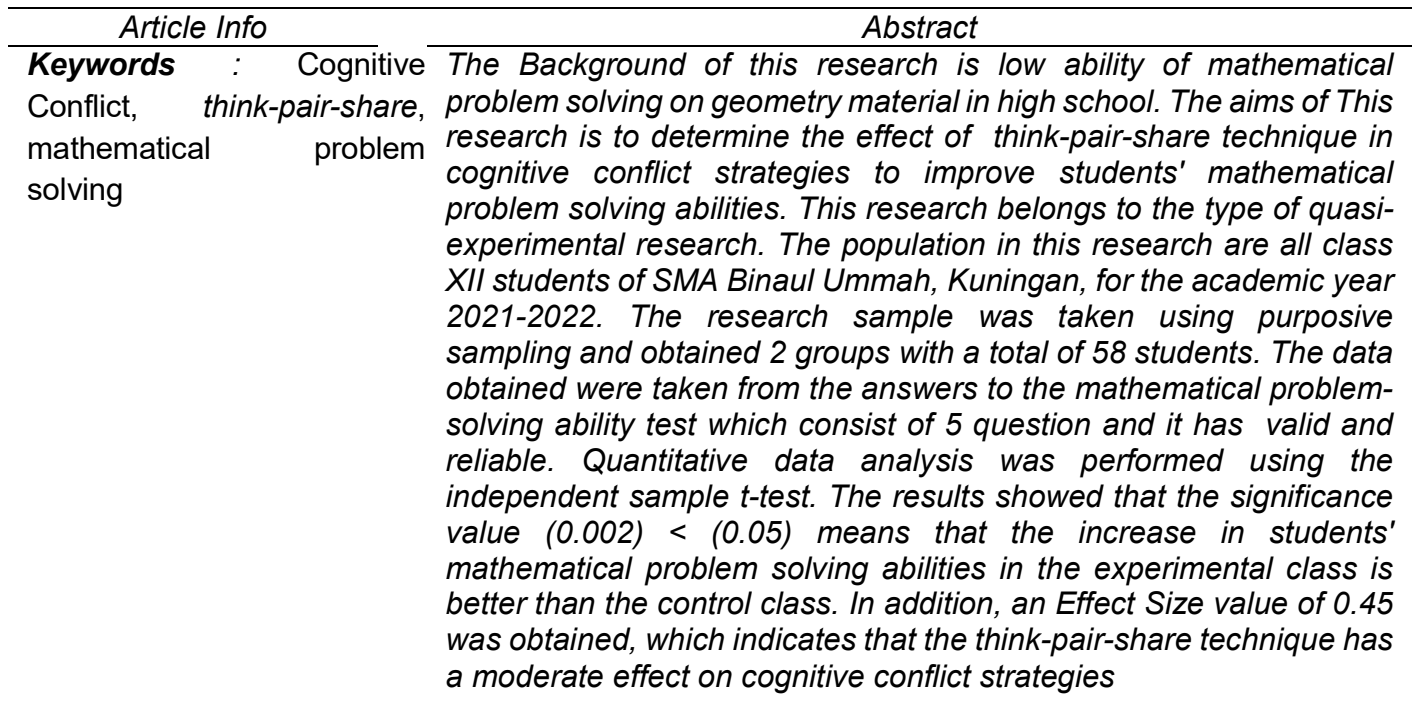

Kata Kunci: Konflik Kognitif, Penelitian ini dilatar belakangi oleh rendahnya kemampuan think-pair-share, pemecahan pemecahan masalah matematis pada materi geometri SMA. Penelitian masalah matematis ini bertujuan untuk mengetahui besarnya pengaruh teknik think-pairshare dalam strategi konflik kognitif untuk meningkatkan kemampuan pemecahan masalah matematis siswa. Penelitian ini termasuk jenis penelitian kuasi eksperimen. Populasi dalam penelitian ini adalah seluruh siswa kelas XII SMA Binaul Ummah Kabupaten Kuningan 
tahun pelajaran 2021-2022. Pengambilan sampel penelitian menggunakan purposive sampling dan didapat 2 kelompok dengan jumlah 58 siswa. Data yang diperoleh diambil dari jawaban soal tes kemampuan pemecahan masalah matemais berupa soal uraian sebanyak 5 butir soal yang valid dan reliabel. Analisis data kuantitatif dilakukan dengan menggunakan uji independent sample $t$-test. Hasil penelitian memperlihatkan bahwa nilai signifikansi $(0,002)<\alpha(0,05)$ artinya peningkatan kemampuan pemecahan masalah matematis siswa di kelas eksperimen lebih baik dibandingkan dengan kelas kontrol. Selain itu, diperoleh nilai Effect Size sebesar 0,45 yang menunjukkan bahwa teknik think-pair-share memberikan efek sedang pada strategi konflik kognitif

\section{PENDAHULUAN}

Kemendikbud (2013) menyatakan bahwa tujuan diajarkannya matematika adalah memahami konsep matematika, menjelaskan keterkaitan antar konsep, serta mengaplikasian konsep atau algoritma secara luwes, akurat, efisien, dan tepat dalam pemecahan masalah. Hal ini sejalan dengan pendapat Ruseffendi (Sidiq, 2013) yang mengemukakan bahwa kemampuan pemecahan masalah amatlah penting dalam matematika, bukan saja bagi mereka yang dikemudian hari akan mendalami atau mempelajari matematika, melainkan juga bagi mereka yang akan menerapkannya dalam bidang studi lain dan dalam kehidupan sehari-hari.

Beberapa penelitian menunjukkan bahwa kemampuan pemecahan masalah matematis siswa masih jauh dari harapan. Penelitian Adiputra (2015) menyebutkan bahwa dari 12 siswa yang mengerjakan soal pemecahan masalah materi bangun datar, tidak ada satu pun siswa yang menjawab dengan benar. Dari analisis hasil jawaban siswa, dapat dilihat bahwa sebenarnya 40 siswa tersebut mengetahui aturan-aturan (rumus) yang berkaitan dengan bagian dari soal tersebut, namun, ia tidak dapat melakukan suatu rencana penyelesaian sehingga aturan-aturan yang ia ketahui tidak dapat diaplikasikan ke dalam solusi pemecahan masalah. -aturan yang ia ketahui tidak dapat diaplikasikan ke dalam solusi pemecahan masalah. Hal ini sejalan dengan temuan Rahmad (2012), yang menyatakan bahwa kesulitan belajar geometri siswa adalah kurang memahaminya konsep tentang bangun datar. Hal ini terkait dengan objek geometri yang abstrak. Siswa kesulitan apabila langsung dihadapkan pada notasi atau simbol matematika. Hasil penelitian Nugraha \& Zanthy (2018) menunjukkan bahwa hanya 6 dari 22 siswa atau sekitar 26,52\% siswa SMA yang mampu menyelesaikan soal pemecahan masalah yang diberikan.

Berdasarkan uraian di atas kemampuan pemecahan masalah matematis pada materi geometri dirasa perlu diteliti. Karakteristik soal geometri yang sangat rumit memerlukan strategi belajar 
yang dapat mengakomodasi perubahan struktur kognitif siswa. Lee \& Kwon (Lee, dkk., 2003) menjelaskan model proses konflik kognitif dikembangkan untuk menjelaskan konflik kognitif yang terjadi ketika seorang siswa dihadapkan dengan situasi anomali yang tidak sesuai dengan prakonsepsi nya dalam mempelajari pengetahuan. Model ini memiliki tiga tahap (Lee, dkk., 2003), yaitu : tahap awal, tahap konflik, dan resolusi.

Ismaimuza, (2013) berpendapat bahwa pembelajaran dengan strategi konflik kognitif mampu mendorong pelajar memahami, membina pengetahuannya sendiri sehingga mampu mengusai suatu konsep. Strategi konflik kognitif ini berkembang berdasarkan pada asumsi yang menyebutkan bahwa pengetahuan siswa yang sebelumnya mempengaruhi bagaimana cara mereka mempelajari pengetahuan yang baru dan membentuk gambaran ide yang baru. Strategi ini adalah sebuah keadaan dimana siswa merasa adanya ketidakcocokan antara strukur kognitif mereka dengan keadaan lingkungan sekitarnya atau antara komponenkomponen dari struktur kognitif mereka (Lee et al,2003).

Prata, et al (2009) berpendapat beberapa peneliti menyimpulkan bahwa konflik kognitif dalam pembelajaran muncul dari proses kolaborasi, ketika siswa saling terlibat untuk membangun pengetahuan bersama. Faktanya, menurut Moshman, Geil dan Kruger (Prata, et al, 2009), mengklaim bahwa konflik kognitif terjadi hanya dalam konteks kooperatif, dan bukan melalui persaingan atau konflik pribadi. Dalam pandangan Moshman dan Geil, konflik kognitif tidak muncul dari para siswa yang berdebat berdasarkan pandangan berpikir mereka masing-masing, tetapi dari pemikiran solusi bersama. Pendapat berbeda dikemukakan oleh Arsenio, Lover dan Shantz (Prata, et al, 2009), yang memberikan bukti bahwa konflik kognitif sering kali mengarah pada konflik pribadi.

Pendapat di atas mengatakan bawha konflik kognitif dapat terjadi secara personal atau dengan berkelompok. Salah satu aktifitas yang bisa dilakukan secara personal maupun berkelompok adalah dengan menggunakan teknik Think-pair-share. Teknik ini memberi siswa kesempatan untuk bekerja sendiri serta bekerja sama dengan orang lain. Keunggulan lain dari teknik ini adalah optimalisasi partisipasi dari siswa.

Dari uraian di atas, perlu diteliti lebih lanjut masalah-masalah sebagai berikut : (1). Apakah terdapat perbedaan peningkatan kemampuan pemecahan masalah matematis antara siswa yang mendapatkan perlakuan pembelajaran menggunakan strategi konflik kognitif dengan teknik think-pair-share dibandingkan dengan siswa yang mendapatkan perlakuan pembelajaran menggunakan strategi konflik 
kognitif ? (2). Berapa besar teknik think-pairshare memberikan pengaruh pada pembelajaran dengan strategi konflik kognitif ?

\section{METODE}

Penelitian ini termasuk jenis penelitian quasi eksperiment dengan desain Pretestposttest control group design. Pada penelitian ini terdapat dua kelompok siswa yaitu kelompok eksperimen yang mendapatkan pembelajaran dengan strategi konflik kognitif dengan teknik think-pairshare dan kelompok kontrol yang mendapatkan pembelajaran dengan strategi konflik kognitif seperti dalam tabel berikut :

Tabel 1. Desain Penelitian

\begin{tabular}{lccc}
\hline Kelas & Pretest & Perlakuan & $\begin{array}{c}\text { Post- } \\
\text { test }\end{array}$ \\
\hline Eksperimen & $\mathrm{O}_{1}$ & $\mathrm{X}_{1} \mathrm{~T}_{1}$ & $\mathrm{O}_{2}$ \\
Kontrol & $\mathrm{O}_{1}$ & $\mathrm{X}_{1}$ & $\mathrm{O}_{2}$ \\
\hline
\end{tabular}

(Sugiyono, 2011)

Keterangan :

$\mathrm{O}_{1} \quad$ : Pretest sebelum perlakuan

$\mathrm{X}_{1}$ :Pembelajaran Menggunakan

Strategi Konflik Kognitif

$\mathrm{X}_{1} \mathrm{~T}_{1}$ : Pembelajaran Menggunakan

Strategi Konflik Kognitif dengan teknik think-pair-share

$\mathrm{O}_{2} \quad$ : Posttest setelah perlakuan

Populasi dalam penelitian ini adalah seluruh siswa kelas XII di SMA Binaul 42
Ummah tahun pelajaran 2021/2022. Melalui teknik purposive sampling diperoleh 2 sampel yaitu kelompok eksperimen sebanyak 28 siswa dan kelompok kontrol sebanyak 30 siswa. Penelitian ini dilaksanakan pada bulan Agustus 2021 dengan menggunakan instrumen tes yaitu tes kemampuan pemecahan masalah matematis siswa berupa soal uraian sebanyak 5 butir soal yang sudah diuji validitas dan reliabilitasnya. Uji validitas dilakukan kepada mahasiswa tingkat 1 Akademi Maritim Cirebon dengan hasil validitas sebagai berikut : 2 butir soal sangat tinggi, 1 butir soal tinggi, dan 2 butir soal sedang. Sedangkan dari hasil uji reliabilitas diperoleh nilai $r=0,71$ yang termasuk kategori tinggi.

Analisis data menggunakan uji independent sample t-test dimana data harus berdstribusi normal terlebih dahulu. Apabila normalitas data tidak terpenuhi, maka uji hipotesis dilakukan menggunakan uji nonparametrik yaitu uji Mann-Whitney.

\section{HASIL PENELITIAN DAN PEMBAHASAN Hasil Penelitian}

1) Analisis Data Pretest

Data Pretest didapat sebelum diberikan perlakuan kepada kedua kelas. Tujuannya adalah untuk mengetahui apakah terdapat perbedaan kemampuan pemecahan masalah matematis diantara kedua 
kelas tersebut. Berikut adalah statistika deskriptif data Pretest

Tabel 2. Statistik Deskriptif Data Pretest

\begin{tabular}{|c|c|c|}
\hline Data & Eksperimen & Kontrol \\
\hline $\mathrm{n}$ & 28 & 30 \\
\hline Mean & 10,93 & 10,37 \\
\hline Min & 0 & 10 \\
\hline Max & 20 & 20 \\
\hline SD & 5,41 & 1,83 \\
\hline
\end{tabular}

Dari tabel di atas terlihat bahwa ratarata pretest kelas eksperimen sedikit lebih tinggi dari rata-rata kelas kontrol, untuk mengetahui apakah terdapat perbedaan rata-rata pretest dari kedua kelas, akan dilakukan uji hipotesis dengan terlebih dahulu dilakukan uji normalitas.

Tabel 3. Uji normalitas data Pretest

\begin{tabular}{|l|l|l|}
\hline Kelas & $\begin{array}{l}\text { Sig } \\
\text { (Shapir } \\
\text { o- Wilk) }\end{array}$ & $\begin{array}{l}\text { Keteranga } \\
\mathbf{n}\end{array}$ \\
\hline $\begin{array}{l}\text { Eksperime } \\
\mathrm{n}\end{array}$ & 0,113 & $\begin{array}{l}\text { Berdistribu } \\
\text { si normal }\end{array}$ \\
\hline Kontrol & 0,000 & $\begin{array}{l}\text { Tidak } \\
\text { berdistribu } \\
\text { si normal }\end{array}$ \\
\hline
\end{tabular}

Dari tabel 3 dapat dilihat bahwa data kelas kontrol tidak berdistribusi normal, oleh karena itu untuk mengetahui perbedaan rata-rata kedua kelas, digunakan uji non parametrik yaitu uji Mann-Whitney.

Tabel 4. Uji Mann-Whitney Data Pretest

\begin{tabular}{|c|c|}
\hline Sig (2 tailed) & Keterangan \\
\hline 0,963 & $H_{\circ}$ diterima \\
\hline
\end{tabular}

Dari tabel 4 dapat dilihat bahwa nilai signifikansi untuk uji Mann-Whitney yaitu 0,963 dimana lebih besar dari a $(0,05)$. Maka kesimpulannya adalah tidak terdapat perbedaan nilai pretest antara kelas eksperimen dan kelas kontrol. Jadi, sebelum diberlakukan perlakuan, kemampuan pemecahan masalah matematis kedua kelas tidak berbeda.

\section{2) Analisis Data Posttest}

Data posttest didapat setelah diberikan perlakuan kepada kedua kelas yaitu pembelajaran menggunakan strategi konflik kognitif dengan teknik think-pair-share pada kelas eksperimen, dan pembelajaran dengan strategi konflik kognitif pada kelas kontrol. Tujuannya adalah untuk mengetahui apakah terdapat perbedaan kemampuan pemecahan masalah matematis diantara kedua kelas tersebut. Berikut adalah statistika deskriptif data posttest. 
Tabel 5. Statistik Deskriptif Data

Posttest

\begin{tabular}{|l|l|l|}
\hline Data & Eksperimen & Kontrol \\
\hline $\mathrm{n}$ & 28 & 30 \\
\hline Mean & 28,57 & 23,4 \\
\hline Min & 17 & 14 \\
\hline Max & 45 & 38 \\
\hline SD & 10,26 & 5,39 \\
\hline
\end{tabular}

Dari tabel 5 dapat kita lihat bahwa rata-rata kelas eksperimen lebih besar daripada rata-rata kelas kontrol. Untuk mengetahui apakah terdapat perbedaan rata-rata posttest dari kedua kelas, maka terlebih dahulu akan dilakukan uji normalitas data posttest

Tabel 6. Uji Normalitas Data Posttest

\begin{tabular}{|l|l|l|}
\hline Kelas & $\begin{array}{l}\text { Sig } \\
\text { (Shapir } \\
\text { o- Wilk) }\end{array}$ & $\begin{array}{l}\text { Keteranga } \\
\mathbf{n}\end{array}$ \\
\hline $\begin{array}{l}\text { Eksperime } \\
\mathrm{n}\end{array}$ & 0,074 & $\begin{array}{l}\text { Berdistribu } \\
\text { si normal }\end{array}$ \\
\hline Kontrol & 0,239 & $\begin{array}{l}\text { Berdistribu } \\
\text { si normal }\end{array}$ \\
\hline
\end{tabular}

Dari hasi uji normalitas pada kedua kelas diperoleh nilai signifikansi untuk kelas eksperimen sebesar 0,074 dan kelas kontrol sebesar 0,239 . Maka dapat disimpulkan bahwa data kedua kelas berdistribusi normal. Selanjutnya akan dilakukan uji homogenitas untuk mengetahui varians dari kedua kelas.

Tabel 7. Uji Homogenitas Data Posttest

\begin{tabular}{|l|l|l|}
\hline Data & $\begin{array}{l}\text { Sig } \\
\text { (Levene) }\end{array}$ & Keterangan \\
\hline Posttest & 0,056 & $\mathrm{H}_{\circ}$ diterima \\
\hline
\end{tabular}

Dari tabel 7 dapat dilihat nilai signifikansi untuk uji Levene sebesar 0,056 . Karena nilai sig $>0,05$ maka dapat dikatakan bahwa kedua kelas berasal dari populasi yang homogen. Selanjutnya akan diuji hipotesis penelitian ini dengan menggunakan uji independent sample t-test sebagai berikut :

Tabel 8. Uji Independent Sample t-

\begin{tabular}{|c|c|c|l|}
\multicolumn{4}{|c|}{ test data Posttest } \\
\hline Uji & df & Sig & $\begin{array}{l}\text { Keter } \\
\text { angan }\end{array}$ \\
\hline $\begin{array}{l}\text { Independent } \\
\text { sample t-test }\end{array}$ & 56 & 0,004 & $\begin{array}{l}\mathrm{H}_{\circ} \\
\text { ditolak }\end{array}$ \\
\hline
\end{tabular}

Berdasarkan data pada tabel 8 , dapat dilihat bahwa nilai sig $<0,05$, maka kesimpulannya $\mathrm{H}_{\mathrm{o}}$ ditolak artinya terdapat perbedaan rata-rata antara kelas eksperimen dan kelas kontrol.

\section{3) Analisis Data N-Gain}

Untuk mengetahui peningkatan kemampuan pemecahan masalah 
matematis, maka digunakan data $\mathrm{N}$ Gain. Tujuannya adalah untuk mengetahui apakah terdapat perbedaan peningkatan kemampuan pemecahan masalah matematis diantara kedua kelas tersebut. Berikut adalah statistik deskriptif data $\mathrm{N}$-Gain.

Tabel 9. Statistik Deskriptif Data NGain

\begin{tabular}{|c|c|c|}
\hline Data & Eksperimen & Kontrol \\
\hline $\mathrm{n}$ & 28 & 30 \\
\hline Mean & 0,46 & 0,33 \\
\hline Min & 0,12 & 0,1 \\
\hline Max & 0,84 & 0,62 \\
\hline SD & 0,23 & 0,13 \\
\hline
\end{tabular}

Dari tabel di atas dapat dilihat bahwa rata-rata $\mathrm{N}$-Gain kelas eksperimen lebih besar dibandingkan rata-rata kelas kontrol. Untuk mengetahui perbedaan peningkatan kemampuan pemecahan masalah matematis, dilakukan uji perbedaan dua rata-rata. Sebelumnya, akan diuji normalitas kedua sampel terlebih dahulu.

Tabel 10. Uji Normalitas Data N-Gain

\begin{tabular}{|l|l|l|}
\hline Kelas & $\begin{array}{l}\text { Sig } \\
\text { (Shapiro- } \\
\text { Wilk) }\end{array}$ & $\begin{array}{l}\text { Keterang } \\
\text { an }\end{array}$ \\
\hline $\begin{array}{l}\text { Eksperi } \\
\text { men }\end{array}$ & 0,551 & $\begin{array}{l}\text { Berdistribu } \\
\text { si normal }\end{array}$ \\
\hline Kontrol & 0,566 & $\begin{array}{l}\text { Berdistribu } \\
\text { si normal }\end{array}$ \\
\hline
\end{tabular}

Dari tabel 10 dapat dilihat bahwa nilai signifikansi kelas eksperimen dan kelas kontrol >0,05. Maka dapat diambil kesimpulan bahwa data kedua kelas berdistribusi normal. Selanjutnya akan dilakukan uji homogenitas untuk melihat apakah varians kedua kelompok berasal dari populasi yang homogen atau tidak.

Tabel 11. Uji Homogenitas Data NGain

\begin{tabular}{|l|l|l|}
\hline Data & $\begin{array}{l}\text { Sig } \\
\text { (Levene) }\end{array}$ & Keterangan \\
\hline N_Gain & 0,149 & $\mathrm{H}_{\circ}$ diterima \\
\hline
\end{tabular}

Dari hasil uji homogenitas, didapat nilai signifikansi yang lebih besar dari a (0,05). Maka dapat diambil kesimpulan bahwa kedua kelas berasal dari populasi yang homogen. Selanjutnya untuk mengetahui perbedaan peningkatan kemampuan pemecahan masalah matematis, dilakukan uji independent sample ttest dari data $N$-Gain sebagai berikut : Tabel 12. Uji Independent Sample ttest data $\mathrm{N}$-Gain

\begin{tabular}{|c|c|c|c|}
\hline Uji & df & Sig & $\begin{array}{c}\text { Ketera } \\
\text { ngan }\end{array}$ \\
\hline $\begin{array}{l}\text { Independent } \\
\text { sample } t \text {-test }\end{array}$ & 56 & 0,002 & $\begin{array}{l}\mathrm{H}_{\circ} \\
\text { ditolak }\end{array}$ \\
\hline
\end{tabular}

Dari hasil uji perbedaan dua ratarata pada tabel 12 di atas, diperoleh 
nilai signifikansi sebesar $0,002<\alpha$ $(0,05)$. Maka $H_{\circ}$ ditolak dan dapat diambil kesimpulan bahwa terdapat perbedaan peningkatan kemampuan pemecahan masalah matematis antara kelas eksperimen dan kelas kontrol. Dengan kata lain, penggunaan teknik think-pair-share memiliki pengaruh pada pembelajaran dengan strategi konflik kognitif.

\section{4) Effect Size}

Dari perhitungan effect size untuk data $N$-Gain yang dibuat dalam skala persen, diperoleh data sebagai berikut :

\begin{tabular}{|c|c|c|}
\hline Data & Eksperimen & Kontrol \\
\hline $\mathrm{n}$ & 28 & 30 \\
\hline Mean & 46 & 33 \\
\hline $\mathrm{SD}$ & 0,23 & 0,13 \\
\hline
\end{tabular}

Dengan rumus standar deviasi gabungan, diperoleh nilai $s_{g}=28,04$. Untuk mencari besarnya effect size, digunakan rumus Cohen. $E S=\frac{\bar{x}_{t}-\bar{x}_{c}}{S_{g a b}}$. dengan data di atas, diperoleh nilai Effect Size sebesar 0,45. Berdasarkan kriteria, maka teknik think-pair-share memiliki efek sedang pada pembelajaran dengan strategi konflik kognitif.

\section{PEMBAHASAN}

Pada penelitian ini, peneliti bertindak sebagai pengajar matematika. Pokok bahasan penelitian yaitu materi dimensi 3 kelas XII SMA dengan materi menentukan jarak antar titik, jarak titik ke garis dan jarak titik ke bidang. Pembelajaran di kelas eksperimen dan kelas kontrol dilakukan dengan bantuan Lembar Kerja Siswa (LKS) yang mana isinya sudah memuat masalahmasalah yang mengakibatkan terjadinya konflik kognitif bagi siswa. Misalnya, dalam menentukan jarak titik ke bidang, diberikan ilustrasi jarak proyektor (yang dipasang di atas) ke lantai. Siswa menyampaikan beberapa pendapat sehingga diperoleh kesimpulan bagaimana caranya menentukan jarak dari titik ke bidang. Kemudian, dengan melihat latihan soal pada LKS, siswa diminta menentukan jarak titik ke bidang dalam bangun limas segi empat. Disini tentu terjadi konflik kognitif dimana pengetahuan awal yang dibangun siswa adalah menentukan jarak dalam bidang berbentuk balok, sedangkan masalah yang harus mereka selesaikan adalah menentukan jarak pada bidang berbentuk limas dimana sisi yang ditujunya berbentuk segitiga. Pada kegiatan ini, perlakuan pada kelas eksperimen dan kelas kontrol dibedakan dengan teknik think-pair-share. Pada kelas eksperimen, dalam proses ini peneliti memberikan waktu kepada siswa untuk berpikir (think) bagaimana mencari 
langkah-langkah pemecahan masalahnya sedangkan pada kelas kontrol, proses yang hampir sama dilakukan oleh siswa yaitu secara mandiri berusaha menemukan kaitan antara konsep awal yang didapat dengan masalah yang sedang dihadapi. Kegiatan berikutnya, pada kelas eksperimen peneliti mempersilahkan siswa untuk berpasangan (pair) dengan teman sebangkunya dimana dalam kegiatan ini siswa berdiskusi tentang langkah-langkah penyelesaian yang sudah dipikirkan sebelumnya. Peneliti juga mendatangi setiap pasangan untuk mengetahui hasil diskusinya. Sedangkan pada kelas kontrol, peneliti berkeliling melihat beberapa hasil pekerjaan siswa. Selanjutnya pada kelas eksperimen peneliti mempersilahkan siapa saja yang ingin berbagi (share) tentang hasil diskusinya dalam menyelesaikan masalah yang diberikan. Peneliti memberikan kesempatan kepada setiap pasangan untuk menanggapi hasilnya. Sedangkan pada kelas kontrol, peneliti memberikan scaffolding kepada siswa yang mengalami kesulitan dalam menemukan penyelesaian. Langkahlangkah ini sesuai dengan pendapat Arends (2008 : 15-16) tentang langkah-langkah penerapan teknik think-pair-share.

Kegiatan ini dilakukan untuk setiap latihan soal yang dibuat sangat bervariasi yang terdapat dalam LKS. Pada kegiatan akhir, peneliti memberikan refleksi tentang apa yang dilakukan untuk menyelesaikan masalah yang terdapat dalam LKS misalnya dari langkah-langkah penyelesaian yang sudah ditulis, peneliti melingkari langkah yang dirasa sangat penting untuk dipikirkan, kalau langkah tersebut tidak terpikirkan, maka bisa dipastikan soal tersebut tidak dapat terselesaikan. Kombinasi strategi konflik kognitif dengan teknik think-pairshare membantu siswa dalam mempercepat penyesuaian struktur kognitif terhadap hal yang berbeda dari sebelumnya sehingga penyelesaian konflik (equilibrium) dapat dengan mudah tercapai.

\section{PENUTUP}

\section{Simpulan}

1. Berdasarkan analisis data N-Gain berupa uji independent sample t-test. Diperoleh ilaisignifikansi sebesar $0,002>\alpha(0,05)$. Kesimpulannya $\mathrm{H}_{\mathrm{o}}$ ditolak. Artinya terdapat perbedaan rata-rata nilai $N$-Gain antara kelas eksperimen dan kelas kontrol.

2. Dilihat dari nilai effect size, diperoleh skor sebesar 0,45 artinya teknik thinkpair-share memberikan berpengaruh yang sedang pada pembelajaran dengan strategi konflik kognitif.

\section{Saran}

Penggunaan beberapa teknik yang lain pada pembelajaran dengan strategi konflik kognitif perlu diteliti lebih lanjut di berbagai jenjang pendidikan, sehingga 
menambah wawasan dalam penggunaan metode pembelajaran oleh guru.

\section{DAFTAR PUSTAKA}

Adiputra, Y. 2015. Tesis. Analisis Proses Berpikir Siswa dalam Pemecahan Masalah Matematis dan Efektivitas Strategi Abduktif - Deduktif untuk Mengatasi Kesulitannya. Bandung: SPs UPI . Tidak diterbitkan.

Arends, Richard I. 2008. Learning to Teach: Belajar untuk Mengajar. Yogyakarta: Pustaka Pelajar.

Ismaimuza, D. (2013). Kemampuan Berpikir Kritis dan Kreatif Matematis Siswa SMP Melalui Pembelajaran Berbasis Masalah dengan Strategi Konflik Kognitif. Jurnal Teknologi (Sciences \& Engineering) 63:2 (2013), 33-37.

Kemendikbud. 2013. Handout Pelatihan Kurikulum 2013. Jakarta:

Kemendikbud

Lee, G. dkk.(2003). Development of an instrument for measuring cognitive conflict inSecondary-Level Science Classes.Journal of Research in Science Teaching, 40 (6),hlm.585603.

Prata, et.al. (2009). Detecting and Understanding the Impact of Cognitive and Interpersonal Conflict in Computer Supported Collaborative
Learning Environments. International Conference on Educational Data Mining (EDM) Cordoba, Spain

Rahman, S.A. 2013. Peningkatan Kemampuan Pemecahan Masalah, Kemampuan Berpikir Reflektif Matematis, dan Adversity Quotient Siswa SMP dengan Pendekatan Open-Ended. Tesis : UPI. Bandung : Tidak Diterbitkan.

Nugraha, A., \& Zanthy, L. 2018. Analisis Kemampuan Pemecahan Masalah Siswa SMA Pada Materi Sistem Persamaan Linear. Journal on Education,1(2), 179-187.

Rahmad, N.B. 2012. Analisis Kesulitan Siswa SMK pada Materi Pokok Geometri Dan Alternatif Pemecahannya. Makalah Seminar Nasional Pendidikan Matematika : Surakarta

Sugiyono. 2011. Metode Penelitian Pendidikan Pendekatan Kuantitatif, Kualitatif, dan R\&D. Bandung : Alfabeta. 